\title{
A brief review on molecular, genetic and imaging techniques for HCV fibrosis evaluation
}

Waqar Ahmad, Bushra ljaz, Sana Gull, Sultan Asad, Saba Khaliq, Shah Jahan, Muhammad T Sarwar, Humera Kausar, Aleena Sumrin, Imran Shahid, Sajida Hassan

\begin{abstract}
Background: Chronic HCV is one of the major causes of morbidity and mortality in the present day world. The assessment of disease progression not only provides useful information for diagnosis and therapeutic supervision judgment but also for monitoring disease. Different invasive and non invasive methods are applied to diagnose the disease from initial to end stage (mild fibrosis to cirrhosis). Although, liver biopsy is still considered as gold standard to identify liver histological stages, an assessment of the disease development based on non-invasive clinical findings is also emerging and this may replace the need of biopsy in near future. This review gives brief insight on non-invasive methods currently available for predicting liver fibrosis in HCV with their current pros and cons to make easier for a clinician to choose better marker to assess liver fibrosis in HCV infected patients.
\end{abstract}

Methods: More than 200 studies regarding invasive and noninvasive markers available for HCV liver disease diagnosis were thoroughly reviewed. We examined year wise results of these markers based on their sensitivity, specificity, PPV, NPV and AUROCs.

Results: We found that in all non-invasive serum markers for HCV, FibroTest, Forn's Index, Fibrometer and HepaScore have high five-year predictive value but with low AUROCs (0.60 0.85) and are not comparable to liver biopsy (AUROC $=0.97$ ). Even though from its beginning, Fibroscan is proved to be best with high AUROCs $(>0.90)$ in all studies, no single noninvasive marker is able to differentiate all fibrosis stages from end stage cirrhosis. Meanwhile, specific genetic markers may not only discriminate fibrotic and cirrhotic liver but also differentiate individual fibrosis stages.

Conclusions: There is a need of marker which accurately determines the stage based on simplest routine laboratory test. Genetic marker in combination of imaging technique may be the better non invasive diagnostic method in future.

\section{Introduction}

Chronic Hepatitis C (HCV) is one of the major causes of liver fibrosis, with distortion of the hepatic architecture, and ultimate progression to cirrhosis. Approximately more than $3 \%$ of the total world population is chronically infected with $\mathrm{HCV}$ and due to gradual increase in the prevalence of $\mathrm{HCV}$; future burden of chronic $\mathrm{HCV}$ is predicted to raise at least 3 fold by the year 2020. Common causes of liver fibrosis are viral hepatitis and steato hepatitis with alcohol or obesity. Fibrosis caused by excessive deposition of extracellular

\footnotetext{
* Correspondence: sajihassan2004@yahoo.com

Applied and Functional Genomics Laboratory, Centre of Excellence in Molecular Biology, University of the Punjab, Lahore, Pakistan
}

matrix (ECM) by histological and molecular reshuffling of various components like collagens, glycoproteins, proteoglycans, matrix proteins and matrix bound growth factors. These changes can lead to metabolic and synthesis impairment to hepatocytes, epithelial cells and hepatic stellate cells (HSC). HSC activation the main step leading to fibrosis, involves several changes in liver like fibrogenesis, proliferation, contractility, chemotaxis, matrix degradation and cytokine release. Fibrosis can be defined as net result of the balance between ECM production and degradation. As ECM tissues not only involve matrix production but also matrix degradation leading to ECM remodeling, fibrosis is potentially a reversible process in early stages (advance stages in some cases) [1-6].

\section{C) Biomed Central}


Fibrosis stages information not only indicate treatment response but also reflect/indicate cirrhosis development disaster. We can evaluate fibrosis in $\mathrm{HCV}$ infected patients invasively or non-invasively. Liver biopsy an invasive method is used for histological scoring and still used as reference test for fibrosis staging. With the increasing knowledge of molecular biology, genetics and availability of modern imaging techniques, many clinicians and related scientists developed several noninvasivemethods to assess liver fibrosis and cirrhosis. These markers need to be more precise, reproducible and non-invasive to evaluate liver fibrosis in $\mathrm{HCV}$ infected patients. Therefore, an assessment of the disease development based on clinical findings is still critical for patients infected with HCV. The accuracy of a serological test either individually or in combination is given as the area under the curve (AUC) of the receiver operator characteristic (ROC) of specific serum diagnosis test. In the meantime, genetic marker should reflect differential expression in different fibrosis stages [4,7-13]. This article will focus on the technologies that can be used to assess hepatic fibrosis in HCV infected patients with unequal values. Figure 1 shows an outline of possible methods used for fibrosis evaluation in HCV infected patients.

\section{Invasive Method}

In clinical practice, grading and staging involve semi-quantitative scoring systems, and elementary lesion expressed as a numerical value $[14,15]$. Three scoring systems, Knodell, Ishak and Metavir are extensively used to assess fibrosis [16-18]. In Metavir system, one of the most clinically validated systems; F0-F1 is considered none to mild, F2-F3 moderate to advance fibrosis and F4 as cirrhosis. Liver biopsy, an invasive method is considered the gold standard to identify liver fibrosis. Unfortunately, procedure of liver biopsy is invasive, expensive with severe side effects leading to death and not suitable for all patients. Other

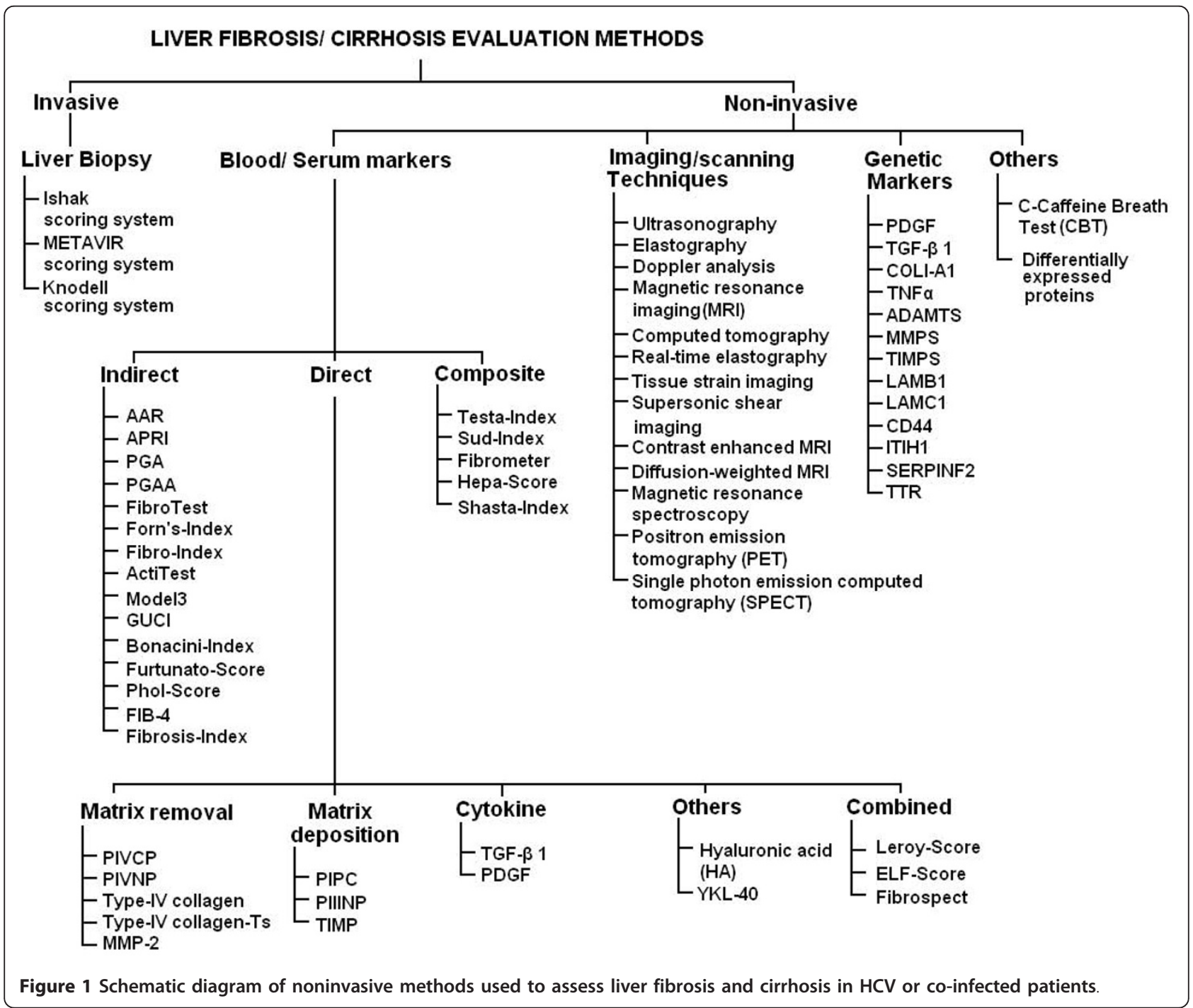


limitations of liver biopsy comprises sampling error, intra and inter observer variation and somehow static, not accurately predict disease progression $[19,20]$.

\section{Non-invasive Methods}

Non-invasive methods can be classified as serum, genetic and imaging techniques. These markers are addressed below in detail.

\section{Serum markers}

Serological markers refer to the measurement of one or more molecules within blood or serum correlating to hepatic fibrosis [21-23]. There are several proposed serological markers or combinations of serum markers for hepatic fibrosis measurement. Their levels vary by changes in their clearance, metabolism, and excretion, and their significant contribution from non-hepatic sources, such as, bones, joints, lungs, kidneys and skin $[24,25]$. Proposed hepatic fibrosis serological markers can be divided in three categories as direct, indirect or composite. Combinations of both direct and indirect, markers are taking place as an emerging and promising alternative to liver biopsy [26-29]. Figure 1 gives a brief idea about the non-invasive methods used for fibrosis and cirrhosis prediction in $\mathrm{HCV}$ infected patients.

\subsection{Direct serum markers}

Direct serum markers reflect ECM turnover, balance between hepatic fibrogenesis and fibrolysis, and in the deposition and removal of ECM. Levels of direct serum markers are elevated during disease progression and an independent association between stage of fibrosis and direct markers was observed [30-32]. Some of the markers reported are discussed below.

\subsubsection{Matrix deposition and removal markers}

These may be classified into following

Procollagen I carboxy terminal peptide (PICP), Procollagen III amino-terminal peptide (PIIINP) and Type IV collagen PICP and PIIINP released into the serum during matrix removal and deposition. PIIINP reflects the stage of fibrosis and known to be elevated in chronic liver disease. PIIINP is a good inflammatory score predictor as compared to fibrosis. PICP usually indicates cirrhosis and used for quantifying disease severity. However, it reflects alcohol etiology better than diagnosis of chronic liver disease. Type IV serum collagen reflects matrix degradation and increased in chronic liver disease. Murawaki et al (1996) established the cutoff value of $110 \mathrm{ng} / \mathrm{mL}$ for stages greater than F2 and $130 \mathrm{ng} / \mathrm{mL}$ for F3 fibrosis stage [33-37].

Matrix metalloproteinase (MMP's) and tissue inhibitor of metalloproteinases (TIMPs) MMP's enzymes produced intracellularly and secreted in a pro-enzyme form that requires cleavage by cell surface mechanisms control matrix degradation. Although these proteins act both to degrade and deposition of ECM, also involve in activation of growth factor, effect on cell proliferation and inhibition of apoptosis; their association with liver fibrosis is not clear [4,23]. TIMPs also increased during HCV infection, while a decrease is reported after interferon therapy. These have high diagnostic ability to detect cirrhosis [38]. Cytokines Two types of cytokines TGF- $\beta 1$ (transforming growth factors $\beta$ 1) and PDGF (platelet derived growth factor) are mainly used to assess the fibrosis progression. TGF- $\beta 1$ is the dominant stimulus for producing extracellular matrix and it showed a significant correlation with degree of hepatic fibrosis. A significant association was found between TGF- $\beta 1$ serum levels and fibrosis progression. Serum level of PDGF has also showed high ability as serum marker for fibrosis progression [39-41].

\subsubsection{Combined direct markers}

FibroSpect FibroSpect assay is a combination of three parameters: HA, TIMP-1 and alpha-2-macroglobulin and can differentiate between no/mild and moderate/ severe fibrosis $[42,43]$. Maximum sensitivity and specificity of this assay was observed at two extreme stages (F0 and F4). This assay was further developed by adding YKL-40 serum marker for assessing Ishak stages and digital quantification of fibrosis [23].

$\boldsymbol{E L F}$ European liver fibrosis group (ELF) developed an algorithm consisted of HA, PIIINP, TIMP-1 and age. However this assay showed low performance while predicting fibrosis in chronic HCV patients [44].Leroy Score

This score was developed by Leroy et al and contains PIIINP and MMP-1 as basic components. It can differentiate between mild and significant fibrosis [45].

\subsubsection{Others}

Hyaluronic acid (HA) HA is best validated, an essential component of extracellular matrix of body tissues. HA levels increases with the fibrosis progression and correlate with the degree of fibrosis and inflammation in chronic HCV patients. The diagnostic accuracy of HA is better than that of PIIINP [32,35,46-49].

Chondrex, human cartilage glycoprotein (YKL-40) In liver fibrosis, YKL-40 plays role in tissue degradation and extracellular matrix remodeling. YKL-40 level is observed to decrease after interferon therapy. In a combination of different direct serum markers, HA and YKL-40 were more useful for monitoring fibrosis progression with $80 \%$ PPV of predicting stage specific fibrosis. A significant association of HA with liver fibrosis was observed when compared with TGF- $\beta 1$ [50-53].

Table 1 briefly describes a year wise overview of the AUROCs, PPV, NPV, sensitivity and specificity of direct serum markers used in various studies to predict fibrosis and cirrhosis in HCV infected patients. Direct serum markers; HA, YKL-40 and ELF were able to predict significant 
Table 1 Diagnostic accuracies of direct serum markers

\begin{tabular}{|c|c|c|c|c|c|c|c|c|}
\hline Markers & Study & Year & Prognosis & Sen & Spe & PPV & NVP & AUC \\
\hline \multirow[t]{5}{*}{ ELF Score } & Rosenberg [44] & 2004 & Fibrosis & 90 & 41 & 99 & 92 & 0.80 \\
\hline & & & Cirrhosis & - & - & - & - & 0.89 \\
\hline & Cales [79] & 2005 & Fibrosis & - & - & - & - & 0.88 \\
\hline & Parkes [12] & 2006 & Fibrosis & - & - & - & - & 0.78 \\
\hline & Lee [107] & 2010 & Cirrhosis & & & & & 0.70 \\
\hline \multirow[t]{3}{*}{ FibroSpect } & Patel [42] & 2004 & Fibrosis & 77 & 73 & 74 & 75 & 0.83 \\
\hline & Cales [79] & 2005 & Fibrosis & - & - & - & - & 0.87 \\
\hline & Zaman [43] & 2007 & Fibrosis & 72 & 74 & 61 & 82 & 0.82 \\
\hline \multirow[t]{11}{*}{$\mathrm{HA}$} & Guechot [34] & 1996 & Fibrosis & 64 & 91 & - & - & 0.86 \\
\hline & & & Cirrhosis & 79 & 89 & - & - & 0.92 \\
\hline & Murawaki [47] & 2001 & Fibrosis & 75 & 80 & 77 & 78 & 0.86 \\
\hline & & & Cirrhosis & 50 & 79 & 42 & 84 & 0.92 \\
\hline & Halfon [49] & 2005 & Fibrosis & 14 & 99 & 94 & 57 & 0.75 \\
\hline & & & Cirrhosis & 31 & 99 & 57 & 96 & 0.89 \\
\hline & Suzuki [48] & 2005 & Fibrosis & 85 & 80 & 51 & 96 & 0.89 \\
\hline & & & Cirrhosis & - & - & - & - & 0.92 \\
\hline & Saitou [51] & 2005 & Fibrosis & 80 & 80 & 80 & 80 & 0.92 \\
\hline & Parise [81] & 2006 & Fibrosis & 85 & 71 & - & - & 0.88 \\
\hline & & & Cirrhosis & 91 & 82 & - & - & 0.91 \\
\hline Leroy Score & Leroy [45] & 2004 & Fibrosis & 43 & 64 & 45 & 40 & - \\
\hline \multirow[t]{6}{*}{ PIIINP } & Guechot [34] & 1996 & Fibrosis & 70 & 63 & - & - & 0.69 \\
\hline & & & Cirrhosis & 60 & 74 & - & - & 0.73 \\
\hline & Murawaki [47] & 2001 & Fibrosis & 74 & 75 & 75 & 92 & - \\
\hline & & & Cirrhosis & 64 & 59 & 33 & 84 & - \\
\hline & Saitou [51] & 2005 & Fibrosis & 78 & 75 & 76 & 77 & 0.75 \\
\hline & & & Cirrhosis & 77 & 66 & 69 & 67 & 0.79 \\
\hline \multirow[t]{2}{*}{ PIVNP } & Murawaki [47] & 2001 & Fibrosis & 70 & 73 & 71 & 72 & - \\
\hline & & & Cirrhosis & 63 & 73 & 41 & 87 & - \\
\hline \multirow[t]{4}{*}{ TIMP } & Murawaki [47] & 2001 & Fibrosis & 79 & 56 & 63 & 73 & - \\
\hline & & & Cirrhosis & 82 & 54 & 34 & 94 & - \\
\hline & Boeker [38] & 2002 & Fibrosis & 52 & 88 & - & - & 0.71 \\
\hline & & & Cirrhosis & 100 & 75 & - & - & 0.90 \\
\hline \multirow[t]{2}{*}{ YKL-40 } & Saitou [51] & 2005 & Fibrosis & 78 & 81 & 80 & 79 & 0.81 \\
\hline & & & Cirrhosis & 80 & 71 & 73 & 78 & 0.80 \\
\hline
\end{tabular}

fibrosis as well as cirrhosis with AUROC 0.70-0.85. However, these markers showed low sensitivity and NPV for predicting fibrosis and high efficiency to detect cirrhosis.

\section{Indirect serum fibrosis markers}

The other category of serum marker is indirect markers that are based on the disturbance of hepatic function or structure.

\subsection{Serum ALT, AST and AFP levels}

Serum ALT released from liver tissue into the circulation in proportion to the degree of hepatocellular damage due to viral infections and toxic substances [54,55]. ALT is thought as one of the more sensitive marker of liver injury and disease progression [56-58]. However, ALT enzymatic activity may not always reflect the degree of hepatic damage as about $26 \%$ patients have persistently normal ALT levels but have a histological score greater than A1F1 [59]. Serum AST levels are most important predictor of histological activity than ALT [60-62]. Serum AFP is alpha-1-globulin secreted by fetal hepatocytes and fetal gastrointestinal tract. Elevated serum AFP levels are associated with acute and chronic $\mathrm{HCV}$, toxic liver injury concentrations and correlate with tumor size and decrease or normalize after tumor removal. Elevated AFP levels are observed in cirrhotic patients [63-66].

\subsection{Platelet count (PLT)}

Decreased production of thrombopoietin by hepatocytes and reduced platelet production is associated with fibrosis progression. Platelet count $\left(<150 \times 10^{9} / \mathrm{L}<100\right)$ can differentiate cirrhotic (F4) from fibrosis (F1-F3) in 75-80\% chronic HCV patients [67-70]. 


\subsection{Prothrombin time (PT)}

PT reflects the synthesis capacity of the liver and essential mechanism of blood coagulation. Its clinical reference range is usually around 12-15 seconds. Prolonged PT is associated with esophageal varices and is one of the earliest indicators of liver cirrhosis [71-73].

\subsection{AST/ALT ratio (AAR)}

Sheth et al. reported an AST/ALT ratio $\geq 1$ having $100 \%$ PPV for the presence of cirrhosis in chronic HCV patients [74]. Reedy et al. observed that AAR failed to predict cirrhosis accurately in $\mathrm{HCV}$ patients [75], while Giannini et al. reported high diagnostic accuracy of the AAR for prediction of cirrhosis in $\mathrm{HCV}$ infected patients [76]. However, many authors could not able to find high accuracy of this marker $[4,70,77]$.

\subsection{AST to platelet ratio Index (APRI)}

APRI was the simplest and accurate test for significant liver fibrosis and cirrhosis [28]. Several authors verified this marker for fibrosis and cirrhosis and found it better than AAR. However, APRI was unable to identify individual stages of fibrosis [77-86].

\subsection{PGA and PGAA Index}

PGA was known to be the original index of hepatic fibrosis in $1990 \mathrm{~s}$ and combines gamma glutamyl transferase $(\gamma \mathrm{GT})$, apolipoprotein A1 (PGA) and prothrombin index. PGAA index is modified form of PGA index by the addition of alpha-2-macroglobulin, resulted in its improved version. The diagnostic accuracy of the PGA and PGAA for detecting cirrhosis reported between 66$72 \%$ and $80 \%$, respectively [87-92].

\subsection{FibroTest/FibroSure}

FibroTest is the combination of five markers: alpha-2macroglobulin, haptoglobin, apolipoprotein $\mathrm{A}_{1}$, GGT and total bilirubin $[26,80]$. This marker has $75 \%$ sensitivity and $85 \%$ specificity with reproducibility for fibrosis diagnosis [83-85]. However, Rossi et al. reported low AUROC (0.739) for significant fibrosis with NPV and PPV $85 \%$ and $78 \%$, respectively. Meanwhile, FibroTest is validated and suggested as an alternative to liver biopsy in chronic HCV patients [93-105].

\subsection{Fibro Index}

It combines three markers; AST, platelet count and gamma globulin. AUROC for prediction of significant fibrosis was 0.83 [106].

\subsection{Forns Index}

This index is based on four available variables; age, GGT, platelet count and cholesterol levels in a study on $\mathrm{HCV}$ patients, included both test and validation cohorts [27]. The limitation of this index was the identification of advance liver disease with minimal fibrosis [79,80,106,107].

\subsection{ActiTest}

ActiTest reflects both necroinflamatory activity and liver cirrhosis. It is modified form of Fibrotest with addition of ALT level (26). Fibrotest and ActiTest were found to be potential non-invasive assays for the assessment of hepatic fibrosis and necro-inflammatory activity in pediatric patients with chronic $\mathrm{HCV}$ in comparison with liver biopsy $[90,91,108]$.

\subsection{SteatoTest}

It incorporates the FibroTest, ALT, body mass index, serum cholesterol, triglycerides and glucose adjusted for age and gender. It has 63\% PPV for steatosis prevalence with 93\% NPV [109].

\subsection{Model 3}

This model is based on AST, platelet count and prothrombin time expressed as international normalized ration (INR). Patients with liver cirrhosis can be excluded at cutoff value of $<0.20$ with 99\% NPV [110,111].

\subsection{Goteborg University Cirrhosis Index (GUCI)}

Islam et al. found strong association between AST, prothrombin-INR and platelet count. By using a cutoff value 1.0 , the sensitivity and specificity for the diagnosis of cirrhosis was $80 \%$ and $78 \%$ respectively, while the NPV and PPV were 97\% and 31\%, respectively [112].

\subsection{Fibrosis Index}

This index comprises of platelet count and albumin contents. It can differentiate significant fibrosis and cirrhosis from mild fibrosis [113].

\subsection{Phol Score}

This index comprises of AST, ALT and platelet count. It showed great accuracy for discriminating significant fibrosis and cirrhosis with high PPV and NPV. However, it showed limited ability to predict fibrosis in later study $[114,115]$.

\subsection{Bonacini Index}

This index incorporates ALT/AST ratio, INR and platelet count. It showed 94\% specificity for predicting significant fibrosis in initial cohort [116].

Table 2 represents the diagnostic accuracies of indirect serum markers. Indirect serum markers are easily available and routinely used. These markers have the ability to differentiate fibrosis and cirrhosis but lesser 
Table 2 Diagnostic accuracies of indirect serum markers

\begin{tabular}{|c|c|c|c|c|c|c|c|c|}
\hline Markers & Study & Year & Prognosis & Sen & Spe & PPV & NVP & AUC \\
\hline \multirow[t]{6}{*}{ AAR } & Sheth [74] & 1998 & Cirrhosis & 53 & 100 & 100 & 81 & 0.85 \\
\hline & Afdhal [4] & 2004 & Fibrosis & 47 & - & - & 88 & - \\
\hline & & & Cirrhosis & - & 96 & 74 & - & - \\
\hline & Lackner [70] & 2005 & Fibrosis & 53 & 100 & - & - & 0.57 \\
\hline & & & Cirrhosis & 36 & 90 & 41 & 87 & 0.73 \\
\hline & Fuji [77] & 2009 & Fibrosis & - & - & - & - & 0.56 \\
\hline \multirow[t]{2}{*}{ ActiTest } & Imbert-Bismut [26] & 2001 & Fibrosis & 91 & 42 & - & - & 0.79 \\
\hline & Halfon [100] & 2008 & Fibrosis & 90 & 38 & - & - & 0.75 \\
\hline \multirow[t]{16}{*}{ APRI } & Wai [28] & 2003 & Fibrosis & 41 & 95 & 64 & 90 & 0.88 \\
\hline & & & Cirrhosis & - & - & 57 & - & 0.94 \\
\hline & Cales [79] & 2005 & Fibrosis & - & - & - & - & 0.79 \\
\hline & Bourliere [80] & 2006 & Fibrosis & 22 & 95 & 63 & 76 & 0.71 \\
\hline & & & Cirrhosis & 38 & 96 & 96 & 40 & 0.81 \\
\hline & Parise [81] & 2006 & Fibrosis & 85 & 66 & - & - & 0.82 \\
\hline & & & Cirrhosis & 73 & 81 & - & - & 0.84 \\
\hline & De Ledinghen [82] & 2006 & Cirrhosis & - & - & - & - & 0.73 \\
\hline & Halfon [83] & 2007 & Fibrosis & 77 & 66 & 61 & 80 & 0.76 \\
\hline & & & Cirrhosis & 100 & 83 & 18 & 100 & 0.92 \\
\hline & Leroy [84] & 2008 & Fibrosis & 39 & 95 & 88 & 62 & 0.79 \\
\hline & Cales [85] & 2008 & Fibrosis & 62 & 83 & 80 & 67 & 0.78 \\
\hline & & & Cirrhosis & - & - & - & - & 0.84 \\
\hline & Kamphues [86] & 2010 & Fibrosis & 70 & 63 & 80 & 80 & 0.68 \\
\hline & & & Cirrhosis & 89 & 44 & 14 & 97 & 0.63 \\
\hline & Fuji [77] & 2009 & Cirrhosis & - & - & - & - & 0.76 \\
\hline Fibro Index & Koda [106] & 2007 & Fibrosis & 36 & 97 & 94 & 59 & 0.83 \\
\hline Fibrosis Index & Ohta [113] & 2006 & Fibrosis & 68 & 71 & 75 & 81 & 0.85 \\
\hline \multirow[t]{17}{*}{ FibroTest } & Imbert-Bismut [26] & 2001 & Fibrosis & 87 & 59 & 63 & 85 & 0.87 \\
\hline & & & Cirrhosis & & & & & \\
\hline & Bedosa [102] & 2003 & Fibrosis & 27 & 97 & 90 & 55 & - \\
\hline & Myers [101] & 2003 & Fibrosis & - & 95 & 88 & - & 0.83 \\
\hline & Poynard [90] & 2003 & Fibrosis & - & - & - & - & 0.73 \\
\hline & Rossi [97] & 2003 & Fibrosis & 83 & 52 & 52 & 83 & 0.74 \\
\hline & Colletta [103] & 2005 & Fibrosis & 64 & 31 & 33 & 62 & - \\
\hline & Bourliere [80] & 2006 & Fibrosis & 55 & 90 & 73 & 79 & 0.82 \\
\hline & De Ledinghen [82] & 2006 & Cirrhosis & - & - & - & - & 0.73 \\
\hline & Halfon [83] & 2007 & Fibrosis & 67 & 80 & 70 & 78 & 0.79 \\
\hline & & & Cirrhosis & 85 & 74 & 11 & 99 & 0.86 \\
\hline & Leroy [84] & 2008 & Fibrosis & 57 & 85 & 78 & 68 & 0.80 \\
\hline & Cales [85] & 2008 & Fibrosis & 67 & 82 & 80 & 70 & 0.81 \\
\hline & Shaheen [104] & 2008 & Fibrosis & 47 & 90 & - & - & 0.81 \\
\hline & & & Cirrhosis & - & - & - & - & 0.90 \\
\hline & Cales [105] & 2010 & Fibrosis & - & - & - & - & 0.81 \\
\hline & & & Cirrhosis & - & - & - & - & 0.88 \\
\hline \multirow[t]{4}{*}{ Forn's Index } & Forn [27] & 2002 & Fibrosis & 94 & 51 & 40 & 96 & 0.78 \\
\hline & Cales [79] & 2005 & Fibrosis & - & - & - & - & 0.82 \\
\hline & Bourliere [80] & 2006 & Fibrosis & 30 & 96 & 65 & 83 & 0.76 \\
\hline & Koda [106] & 2007 & Fibrosis & - & - & - & - & 0.79 \\
\hline Model 3 & Lok [110] & 2005 & Cirrhosis & 10 & 100 & 100 & 86 & 0.78 \\
\hline \multirow[t]{3}{*}{ PGA } & Teare [87] & 1993 & Fibrosis & 94 & 81 & - & - & - \\
\hline & & & Cirrhosis & - & - & 86 & - & - \\
\hline & Poynard [90] & 2003 & Fibrosis & 91 & 81 & - & - & - \\
\hline
\end{tabular}


Table 2 Diagnostic accuracies of indirect serum markers (Continued)

\begin{tabular}{ccccccccc}
\hline \multirow{2}{*}{ PGAA } & Poynard [91] & 2004 & Fibrosis & 79 & 89 & - & - & - \\
Phol Score & Naveau [92] & 2005 & Cirrhosis & 89 & 79 & - & - & 0.93 \\
& Pohl [114] & 2001 & Fibrosis & 41 & 99 & 93 & 85 & - \\
& Cheung [115] & 2008 & Fibrosis & - & - & - & - & 0.53 \\
\hline
\end{tabular}

extent to direct serum markers. APRI and FibroTest are most validated serum markers with AUROC range between $0.60-0.85$ for predicting fibrosis and cirrhosis.

\section{Composite fibrosis markers}

\subsection{FibroMeter}

FibroMeter can differentiate fibrosis progression in viral disease consist of combination of HA, AST, platelet count, prothrombin index, alpha-2-macroglobulin, urea and age of the patients [105].

\subsection{Hepascore}

Hepascore is a model consisting of bilirubin, GGT, HA, alpha-2-macroglobulin, gender and age. AUROC of this test is $0.85,0.96$ and 0.94 for significant fibrosis, advanced fibrosis and cirrhosis, respectively [117-120].

\subsection{Shasta Index}

It combines HA, AST and albumin. Optimal results of this assay are observed in extreme conditions. This assay showed similar accuracy with FibroTest [121].

Table 3 Prognosis accuracies of combined serum markers

\begin{tabular}{|c|c|c|c|c|c|c|c|c|}
\hline Markers & Study & Year & Prognosis & Sen & Spe & PPV & NVP & AUC \\
\hline \multirow[t]{9}{*}{ FIB-4 } & Sterling [122] & 2006 & Fibrosis & 70 & 74 & 42 & 71 & 0.80 \\
\hline & & & Cirrhosis & & & & & \\
\hline & De Ledingh [82] & 2006 & Cirrhosis & - & - & - & - & 0.73 \\
\hline & Vallet-Pichard [123] & 2007 & Fibrosis & 74 & 80 & 82 & 95 & 0.85 \\
\hline & Cales [85] & 2008 & Fibrosis & 74 & 72 & 74 & 71 & 0.80 \\
\hline & & & Cirrhosis & - & - & - & - & 0.87 \\
\hline & Mallet [124] & 2009 & Fibrosis & 71 & 73 & 52 & 86 & 0.81 \\
\hline & & & Cirrhosis & - & - & - & - & 0.87 \\
\hline & Lee [107] & 2010 & Cirrhosis & - & - & - & - & 0.71 \\
\hline \multirow[t]{6}{*}{ Fibrometer } & Halfon [83] & 2007 & Fibrosis & 92 & 87 & 21 & 100 & 0.94 \\
\hline & & & Cirrhosis & 62 & 87 & 21 & 100 & 0.94 \\
\hline & Cales [85] & 2008 & Fibrosis & - & - & - & - & 0.90 \\
\hline & & & Cirrhosis & - & - & - & - & 0.90 \\
\hline & Cales [105] & 2010 & Fibrosis & - & - & - & - & 0.88 \\
\hline & & & Cirrhosis & - & - & - & - & 0.88 \\
\hline Fortunato Score & Fortunato [127] & 2001 & Fibrosis & - & 94 & - & - & - \\
\hline \multirow[t]{16}{*}{ HepaScore } & Adams [117] & 2005 & Fibrosis & 63 & 89 & 88 & 90 & 0.82 \\
\hline & & & Cirrhosis & 71 & 89 & - & - & 0.90 \\
\hline & Bourliere [80] & 2006 & Fibrosis & - & - & - & - & 0.82 \\
\hline & & & Cirrhosis & - & - & - & - & 0.90 \\
\hline & Halfon [83] & 2007 & Fibrosis & 77 & 63 & 59 & 80 & 0.76 \\
\hline & & & Cirrhosis & 92 & 72 & 11 & 100 & 0.89 \\
\hline & Leroy [118] & 2007 & Fibrosis & 54 & 84 & 78 & 64 & 0.79 \\
\hline & Leroy [84] & 2008 & Fibrosis & 63 & 80 & 75 & 70 & 0.78 \\
\hline & Cales [85] & 2008 & Fibrosis & 66 & 79 & 77 & 68 & 0.78 \\
\hline & & & Cirrhosis & - & - & - & - & 0.90 \\
\hline & Becker [119] & 2009 & Fibrosis & 82 & 65 & 70 & 78 & 0.81 \\
\hline & & & Cirrhosis & - & - & - & - & 0.88 \\
\hline & Cales [105] & 2010 & Fibrosis & - & - & - & - & 0.78 \\
\hline & & & Cirrhosis & - & - & - & - & 0.89 \\
\hline & Guechot [120] & 2010 & Fibrosis & 77 & 70 & 71 & 77 & 0.81 \\
\hline & & & Cirrhosis & 86 & 74 & 37 & 97 & 0.88 \\
\hline Shasta Index & Kelleher [121] & 2005 & Fibrosis & 88 & 72 & 55 & 94 & 0.87 \\
\hline Sud Index & Sud [125] & 2004 & Fibrosis & 42 & 98 & 97 & 54 & 0.84 \\
\hline Testa Index & Testa [126] & 2006 & Fibrosis & 78 & 79 & - & - & 0.80 \\
\hline
\end{tabular}




\subsection{Apricot (FIB-4)}

This assay combines four markers: AST, ALT, platelet count and age. This index can predict significant fibrosis in patients infected with $\mathrm{HIV} / \mathrm{HCV}$ [122]. Later studies validated this index not only in co-infected patients but also in HCV infected patients $[85,123,124]$.

\subsection{Sud Index}

This assay is also known as FPI comprises of age, AST, cholesterol, insulin resistance and alcohol intake. This index showed high specificity and PPV for detecting advance fibrosis [125].

\subsection{Testa Index}

This index relate platelet count and spleen diameter. This ratio showed $78 \%$ concordance with the histological score [126].

\subsection{Fortunato score}

This model contains fibronectin, prothrombin time, PCHE, ALT, Mn-SOD and $\beta$-NAG as essential components. It has ability to classify cirrhotic from chronic patients with high accuracy in initial and validation cohort [127].

Table 3 gives an idea about the prediction levels of combined serum markers. These markers showed high AUROCs (0.80-0.90) for predicting fibrosis and cirrhosis in HCV infected patients. FIB-4, Fibrometer and Hepascore are most precise and validated serum markers. Combined serum markers are easily available and most preferable non invasive serum markers now a day.

\section{Imaging/scanning techniques}

Imaging techniques are rational noninvasive approach to assess liver fibrosis. Imaging techniques are not only capable to detect changes in the hepatic parenchyma, these can differentiate between moderate and severe fibrosis. However, high cost and lack of validation of concerning studies remains controversial. Brief detail of these techniques is given under, while there limitations are addressed in Table 4.

\subsection{Ultrasonography (US)}

Ultrasonography detects changes appear in liver echogenicity, nodularity and signs of portal hypertension. A number of studies proposed the role of ultrasonography as a non-invasive diagnostic marker of liver fibrosis and revealed a great sensitivity of ultrasonography to detect late stages of progressive hepatic fibrosis, but a limited capability to measure mild or moderate fibrosis. Ultrasound can identify cirrhosis in patients with sensitivity of $84 \%$ and specificity of $100 \%$ and diagnose accurately $94 \%$. Shen et al. observed that the echo pattern of the hepatic surface contributed to diagnostic accuracy, which was also confirmed in a separate study. However, Oberti found ultrasonography as weak diagnostic marker when compared it with other clinical and biochemical examinations [128-133].

\subsection{Transient Elastography (FibroScan): an applicable alternative to liver biopsy}

Transient elastography measures tissue stiffness. It can measure liver sample size 100 times greater than a standard biopsy sample size, as liver biopsy size strongly effects the grading of chronic viral hepatitis [134-137]. FibroScan results reported $100 \%$ sensitivity and specificity for PPV \& NPV respectively (103). In a study of 935 patients Fibroscan was found to be $97 \%$ successful in grading chronic HCV infection [138]. In another study on 711 patients, liver stiffness measurements (LSM) were also found closely related to fibrosis stage [139]. Vizzutti et al. has also reported a good correlation between liver stiffness measurement and HVPG (hepatic venous pressure gradient) in cirrhotic patients. Success rate depends on patient body mass index, observer expertise and inter-coastal spaces with 5\% failure chances. Several authors assess the performance of elastography and configure it best for the diagnosis of fibrosis $[13,86,103,140-149]$. A combination of FibroScan with FibroTest also gives a better understanding to detect fibrosis and cirrhosis with high AUC [104]. Table 5 briefly describes the diagnostic accuracy of FibroScan with or without combination with FibroTest. In all

Table 4 Summarized imaging techniques with their limitations

\begin{tabular}{|c|c|c|}
\hline Method & Technique & Limitations \\
\hline Ultrasonography & Identification of portal hypertension & $\begin{array}{l}\text { Limited capability to measure mild or moderate fibrosis and cirrhosis, contradictory } \\
\text { results }\end{array}$ \\
\hline Elastography & Liver stiffness & Vulnerable measurements due to narrow intercostals spaces, ascites or obesity \\
\hline Doppler Analysis & $\begin{array}{l}\text { Measures velocity of blood flow, } \\
\text { hemodynamic variations }\end{array}$ & Limited data, lack of reproducibility, contradictory results \\
\hline $\begin{array}{l}\text { Magnetic } \\
\text { Resonance Imaging }\end{array}$ & $\begin{array}{l}\text { Observe changes in hepatic } \\
\text { parenchyma }\end{array}$ & High cost, lack of research support \\
\hline $\begin{array}{l}\text { Computed } \\
\text { Tomography }\end{array}$ & $\begin{array}{c}\text { Identifies micro vascular permeability } \\
\text { changes }\end{array}$ & $\begin{array}{c}\text { Recent technique, not much literature is available, can not performed in renal } \\
\text { failure and contrast agent allergic patients }\end{array}$ \\
\hline
\end{tabular}


Table 5 Diagnostic accuracy of Fibroscan with and without FibroTest

\begin{tabular}{|c|c|c|c|c|c|c|c|c|}
\hline Markers & Study & Year & Prognosis & Sen & Spe & PPV & NVP & AUC \\
\hline \multirow[t]{17}{*}{ Fibro Scan } & Ziol [13] & 2005 & Fibrosis & 56 & 91 & 88 & 56 & 0.79 \\
\hline & & & Cirrhosis & 86 & 96 & 78 & 97 & 0.97 \\
\hline & Colletta [103] & 2005 & Fibrosis & 100 & 100 & 100 & 100 & 1.00 \\
\hline & Foucher [139] & 2006 & Fibrosis & 64 & 85 & 90 & 52 & 0.80 \\
\hline & & & Cirrhosis & 77 & 97 & 91 & 92 & 0.96 \\
\hline & Corpechot [145] & 2006 & Fibrosis & - & - & - & - & 0.95 \\
\hline & Ganne-Carrie [146] & 2006 & Cirrhosis & 79 & 95 & 74 & 96 & 0.95 \\
\hline & Kettaneh [138] & 2007 & Fibrosis & - & - & - & - & 0.79 \\
\hline & & & Cirrhosis & - & - & - & - & 0.91 \\
\hline & Shaheen [147] & 2007 & Fibrosis & 64 & 87 & - & - & 0.83 \\
\hline & & & Cirrhosis & - & - & - & - & 0.95 \\
\hline & Friedrich-Rust [148] & 2009 & Fibrosis & - & - & - & - & 0.84 \\
\hline & & & Cirrhosis & - & - & - & - & 0.94 \\
\hline & Kamphues [86] & 2010 & Fibrosis & 72 & 83 & 96 & 58 & 0.81 \\
\hline & & & Cirrhosis & 100 & 65 & 23 & 100 & 0.87 \\
\hline & Sanchez-Conde [149] & 2010 & Fibrosis & 76 & 75 & 70 & 81 & 0.93 \\
\hline & & & Cirrhosis & 100 & 94 & 57 & 100 & 0.99 \\
\hline \multirow[t]{3}{*}{ Fibro Scan + FibroTest } & Castera [160] & 2005 & Fibrosis & - & - & - & - & 0.88 \\
\hline & & & Cirrhosis & - & - & - & - & 0.95 \\
\hline & Shaheen [104] & 2008 & Fibrosis & 47 & 90 & - & - & - \\
\hline
\end{tabular}

studies, FibroScan showed highest AUROC (>0.90) but not more than liver biopsy (AUROC > 0.970).

\subsection{Doppler analysis}

Doppler measures the velocity of blood flow hemodynamic variations in hepatic vasculature, as sever fibrosis causes irregularities and abnormalities in hepatic blood vessels. Recent data indicate a close correlation between arterioportal ratio and degree of fibrosis, higher ratio indicates severe fibrosis (F3-F4) and low ratio shows moderate fibrosis (F1-F2) [150-153].

\subsection{Magnetic resonance imaging (MRI)}

MRI observes changes in hepatic parenchyma. Noninvasive prognosis of liver cirrhosis is proposed by using double contrast material-enhanced MR imaging. This can detect cirrhosis with great sensitivity and specificity of $90 \%$. Combining Doppler ultrasonography with MRI can give a good picture of liver fibrosis in patients suffering with chronic HCV [154-156].

\subsection{Computed tomography (CT)}

CT identifies microvascular permeability changes in a model of liver fibrosis. In a latest study, the severity of liver fibrosis was predicted by heterogeneous enhancement of the liver; hepatic parameters. Perfusion calculated with a dynamic contrast-enhanced single-section CT, linked with the severity of chronic liver disease. However, no well characterized study has specifically evaluated the worth of CT in diagnosing degree of fibrosis. Therefore, currently its role in diagnosis of liver fibrosis is still lacking [157-159].

\subsection{Fibroscan + Fibrotest}

The combination of two useful noninvasive methods, fibroscan and fibrotest showed high AUROC for predicting cirrhosis [104,160].

\subsection{Modified imaging techniques}

Imaging techniques with modification like Real-time elastography, Tissue strain imaging, Supersonic shear imaging, Contrast enhanced MRI, Diffusion-weighted MRI, Magnetic resonance spectroscopy, Positron emission tomography (PET), Single photon emission computed tomography (SPECT) are also in use to evaluate liver fibrosis and cirrhosis with considerable limitations like, lack of data and expertise, high cost, radiation exposure and short half-life of the tracer in PET and SPECT.

\section{Genetic markers for liver fibrosis evaluation}

ECM metabolism is very dynamic process and required an intricate balance between ECM deposition and removal. Several genetic polymorphisms influenced by factors/cytokines and affect fibrosis progression [98]. Genome-wide analysis of abnormal gene expression showed transcript deregulations during $\mathrm{HCC}$ development with identification of novel serum markers differentiating between normal, mild and severe fibrosis. Advantage of genetic markers 


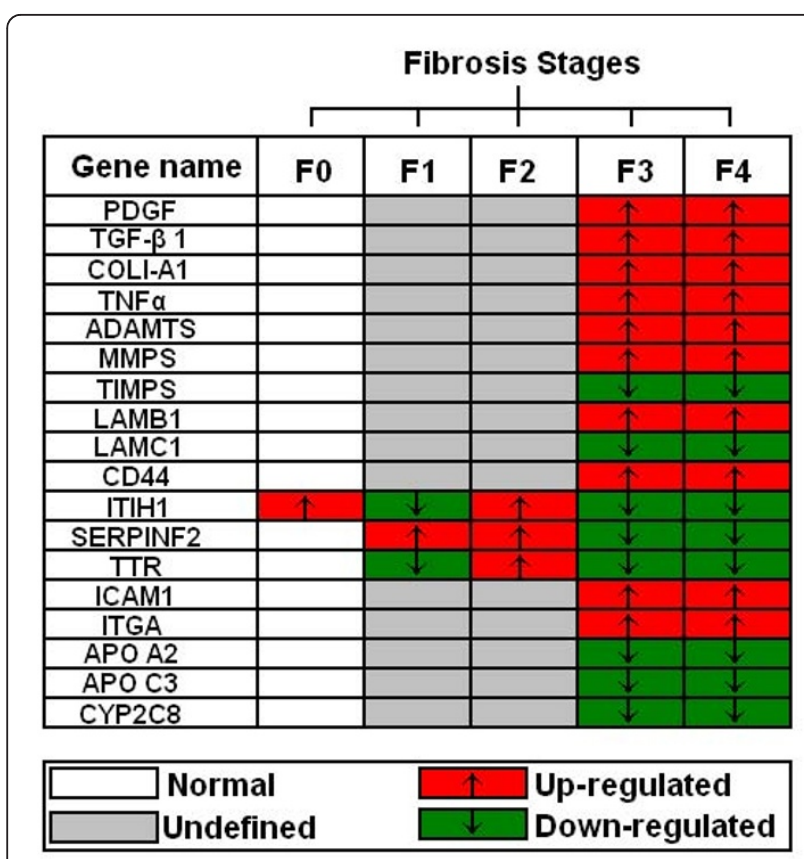

Figure 2 Genes expressed differentially between different fibrosis stages (F0-F3) including cirrhosis (F4).

over liver biopsy is intrinsic and long life while liver biopsy represents only one time point [161-163].

Huang and colleagues developed an assay known as cirrhosis risk score (CRS), a set of seven marker genes to predict cirrhosis risk in $\mathrm{HCV}$ infected patients. Of the seven genes, AZIN1 and TLR4 have an identified role in hepatic fibrosis, while the identification of functional mechanism of the other 5 genes is under process. The authors suggested that fibrosis risk can be identified by host genetic factors like single nucleotide polymorphism (SNP's) [164,165].

A strong association between CXCR3-associated chemokines CXCL9 and CXCL10 with liver fibrosis suggested that they may have promise as new non-invasive markers of liver fibrosis in $\mathrm{HCV}$ infected patients $[166,167]$.

CTGF expression is significantly correlated with fibrosis stages and remarkably increased in advanced stages in HCV patients. The AUROC of CTGF to discriminate between mild and advanced fibrosis is 0.842 for $\mathrm{HCV}$ infected patients [168].

Sharma et al. reported the significant association and elevated interleukin-18 (IL-18) levels in fibrotic and cirrhotic liver stages, severity of disease and necrosis in HCV patients [169].

A recent study by Caillot et al. used microarray technique and found a significant association of ITIH1, SERPINF2 and TTR genes expression and their related proteins with all fibrosis stages. Expression of these genes and related proteins gradually decreased during the fibrosis development to its end stage cirrhosis [170].

A review by Gutierrez-Reyes et al. briefly described role and selection of appropriate genes for fibrosis indication. They briefly explain the role of various genes like PDGF, TGF- $\beta 1$, collagens COL1-A1, TNF $\alpha$, interlukin, ADAMTS, MMPs, TIMPs, LAMB1, LAMC1, Cadherin, CD44, ICAM1, ITGA, APO and CYP2C8 [171]. Figure 2 represents gene clustering according to fibrosis progression on available data.

\section{Others markers for liver fibrosis evaluation} 9.1. C-Caffeine Breath Test (CBT)

Caffeine has high oral bioavailability and undergoes hepatic metabolism and can be use as quantitative test for liver function [172]. Park et al. performed caffeine breath test (CBT) and observed the correlation of orally administrated caffeine with plasma caffeine clearance and degree of liver dysfunction. Chronic patients showed significantly reduced CBT values when compared with controls [173].

\subsection{Differentially expressed proteins}

Differentially expressed proteins were identified by mass spectroscopy among different degrees of fibrosis (F0-F4) and between early (F0-F1) and late (F2-F4) fibrosis. Mac-2-binding protein, alpha-2-macroglobulin and hemopexin levels were found increased while A-1-antitrypsin, leucine-rich alpha-2-glycoprotein and fetuin-A were decreased in advanced fibrosis $\mathrm{F} 4$ as compared to early fibrosis F0/F1 [115].

\section{Clinical utilization and future of non-invasive markers}

Non-invasive markers should be able to differentiate between different fibrosis stages but also reflect the treatment outcome. Even though the invasive liver biopsies considered as gold standard for final assessment of liver fibrosis, non-invasive markers are risk free, reflect the liver status and may offer an attractive alternative to liver biopsy in future. However, none of currently available serum markers completely fulfill these criteria. The outcome of non-invasive markers in several studies is not same. Due to this, non-invasive markers are used in parallel to liver biopsy and not in position to completely replace liver biopsy till date.

Poynard et al. reported the effect of interferon plus ribavirin before and after therapy with respect to FibroTest and Actitest scores. A substantial reduction in FibroTest and Actitest was observed in patients who had showed a sustained virological response $[81,90,115]$. Several other studies reported the down level of serum markers like HA, YKL-40, TIMP-1 and PIIINP after interferon therapy. In these studies, level of serum 
markers continue to fall following treatment but most often return to permanent levels with biochemical and virological relapse. These findings suggest that these assays may be useful for initial staging of disease progression as well as histological response to therapy [174-177]. Fibroscan showed positive correlation with fibrosis stages. However, it is reported that AUROC value of Fibroscan and FibroTest must be improved as their values fall in treated patients irrespective of their virological response $[178,179]$. Furthermore, HCV clearance is associated with a significant reduction in noninvasive fibrosis serological markers like FibroTest, Forns Index, age-platelet ratio index, Shasta, FIB-4, Hepascore and FibroMeter [180]. Patel et al. compared two commercially available serum marker panels Fibrosure and Fibrospect-II in HCV patients during interferon-based therapy. Both assays showed comparable performance for differentiating mild fibrosis from moderate-severe stage [181]. Imaging techniques also have some technical limitations. These are very expensive and are not easy to handle. Their presence in each hospital or laboratory is not possible especially in poor countries. On the other hand genetic markers showed a great variability for detecting cirrhosis and fibrosis. They are also able to differentiate among fibrosis stages. But a lot of work is needed for them to become an integral part of hepatic analysis.

\section{Conclusions}

Our study showed that there are only three to four markers or set of marker that are used continuously based on their precision and accuracy in various studies for fibrosis and cirrhosis prediction. In serum non-invasive markers, FibroTest, Forn's Index, Fibrometer and HeapaScore have a high five-year prognostic value but not compared to liver biopsy (AUROC $=0.97$ ), while Fibroscan showed maximum accuracy nearer to liver biopsy (AUROC > 0.90). Recently, genetic markers showed differential gene expression in different fibrosis stages, but these are not frequently available in all labs. Imaging techniques like ultrasound and elastography not only used to diagnose liver fibrosis but also monitor disease progression. However, genetic markers showed high ability to distinguish not only mild and advance stages of liver fibrosis but also differentiate between intermediate fibrosis stages. Although present published literature do not provide any evidence for non-invasive markers to become an integrated part of the complete assessment of liver fibrosis in HCV patients, a combination of two or more serum markers with imaging techniques may improve the accuracy of diagnosis.

\section{Acknowledgements}

Financial support by Higher Education Commission (Grant \# 863) is highly acknowledged.
Authors' contributions

$A W, I B, G S, A S$ and $H S$ designed the study, analyze the data and wrote paper. JS, KS, SMT, KH, SA and SS checked the revised manuscript thoroughly and confirmed all the data given in manuscript. All work was performed under supervision of HS. All authors read and approved the final manuscript.

\section{Authors' information}

Shah Jahan, Saba Khaliq and Samrin A (PhD in Molecular biology), Bushra ljaz (M Phil Molecular Biology), Waqar Ahmad (M Phil Chemistry) and Gull S (MSc Biochemistry) are Research Officer; Sawar MT and Shahid I are Phd scholars, Asad S is MPhil scholars, while Sajida Hassan (PhD Molecular Biology) is Principal Investigator at CEMB, University of the Punjab, Lahore.

\section{Competing interests}

The authors declare that they have no competing interests.

Received: 18 January 2011 Accepted: 8 February 2011 Published: 8 February 2011

\section{References}

1. Memon Ml, Memon MA: Hepatitis C: an epidemiological review. J Viral Hepat 2002, 9:84-100.

2. WHO: Global distribution of hepatitis A, B and C, 2001. Weakly Epidimiological Records 2002, 77, 41,48.

3. Marcellin P, Asselah T, Boyer N: Fibrosis and disease progression in hepatitis C. Hepatology 2002, 36:547-56.

4. Afdhal NH, Nunes D: Evaluation of liver fibrosis: a concise review. Am J Gastroenterol 2004, 99:1160-1174.

5. Dienstag JL, McHutchison JG: American Gastroenterological Association technical review on the management of hepatitis C. Gastroenterology 2006, 130:231-264, quiz 214-237.

6. Clark JM: The epidemiology of nonalcoholic fatty liver disease in adults. J Clin Gastroenterol 2006, 40(Suppl 1):S5-10.

7. Harbin WP, Robert NJ, Ferrucci JT Jr: Diagnosis of cirrhosis based on regional changes in hepatic morphology: a radiological and pathological analysis. Radiology 1980, 135:273-283.

8. Gressner AM: The cell biology of liver fibrogenesis - an imbalance of proliferation, growth arrest and apoptosis of myofibroblasts. Cell Tissue Res 1998, 292:447-452.

9. Arthur MJ: Reversibility of liver fibrosis and cirrhosis following treatment for hepatitis C. Gastroenterology 2002, 122:1525-1528.

10. Adinolfi $L E$, Gambardella M, Andreana A, Tripodi MF, Utili R, Ruggiero G: Steatosis accelerates the progression of liver damage of chronic hepatitis C patients and correlates with specific HCV genotype and visceral obesity. Hepatology 2001, 33:1358-1364.

11. El-Serag HB: Hepatocellular carcinoma and hepatitis $\mathrm{C}$ in the United States. Hepatology 2002, 36:574-83.

12. Parkes J, Guha IN, Roderick P, Rosenberg W: Performance of serum marker panels for liver fibrosis in chronic hepatitis C. J Hepatol 2006, 44:462-474.

13. Ziol M, Handra-Luca A, Kettaneh A, Christidis C, Mal F, Kazemi F, de Ledinghen V, Marcellin P, Dhumeaux D, Trinchet JC, Beaugrand M: Noninvasive assessment of liver fibrosis by measurement of stiffness in patients with chronic hepatitis C. Hepatology 2005, 41:48-54.

14. Saadeh S, Cammell G, Carey WD, Younossi Z, Barnes D, Easley K: The role of liver biopsy in chronic hepatitis C. Hepatology 2001, 33:196-200.

15. Booth JC, O'Grady J, Neuberger J: Clinical guidelines on the management of hepatitis C. Gut 2001, 49(Suppl 1):11-21.

16. Knodell RG, Ishak KG, Black WC, Chen TS, Craig R, Kaplowitz N, Kiernan TW, Wollman J: Formulation and application of a numerical scoring system for assessing histological activity in asymptomatic chronic active hepatitis. Hepatology 1981, 1:431-435.

17. group TFMCs: Intraobserver and interobserver variations in liver biopsy interpretation in patients with chronic hepatitis C. The French METAVIR Cooperative Study Group. Hepatology 1994, 20:15-20.

18. Ishak K, Baptista A, Bianchi L, Callea F, De Groote J, Gudat F, Denk H, Desmet $V$, Korb G, MacSween RN, et al: Histological grading and staging of chronic hepatitis. J Hepatol 1995, 22:696-699.

19. Goldin RD, Goldin JG, Burt AD, Dhillon PA, Hubscher S, Wyatt J, Patel N: Intra-observer and inter-observer variation in the histopathological assessment of chronic viral hepatitis. J Hepatol 1996, 25:649-654. 
20. Westin J, Lagging LM, Wejstal R, Norkrans G, Dhillon AP: Interobserver study of liver histopathology using the Ishak score in patients with chronic hepatitis C virus infection. Liver 1999, 19:183-187.

21. Friedman SL: Molecular regulation of hepatic fibrosis, an integrated cellular response to tissue injury. J Biol Chem 2000, 275:2247-2250.

22. Friedman SL: Liver fibrosis - from bench to bedside. J Hepatol 2003, 38(Suppl 1):S38-53.

23. Kelleher TB, Afdhal N: Noninvasive assessment of liver fibrosis. Clin Liver Dis 2005, 9:667-683, vii.

24. Idobe $Y$, Murawaki $Y$, Ikuta $Y$, Koda M, Kawasaki H: Post-prandial serum hyaluronan concentration in patients with chronic liver disease. Intern Med 1998, 37:568-575

25. Saif MW, Alexander D, Wicox CM: Serum Alkaline Phosphatase Level as a Prognostic Tool in Colorectal Cancer: A Study of 105 patients. J Appl Res 2005, 5:88-95.

26. Imbert-Bismut F, Ratziu V, Pieroni L, Charlotte F, Benhamou Y, Poynard T: Biochemical markers of liver fibrosis in patients with hepatitis $C$ virus infection: a prospective study. Lancet 2001, 357:1069-1075.

27. Forns X, Ampurdanes S, Llovet JM, Aponte J, Quinto L, Martinez-Bauer E, Bruguera M, Sanchez-Tapias JM, Rodes J: Identification of chronic hepatitis C patients without hepatic fibrosis by a simple predictive model. Hepatology 2002, 36:986-992.

28. Wai CT, Greenson JK, Fontana RJ, Kalbfleisch JD, Marrero JA Conjeevaram HS, Lok AS: A simple noninvasive index can predict both significant fibrosis and cirrhosis in patients with chronic hepatitis C. Hepatology 2003, 38:518-526.

29. Thabut D, Simon M, Myers RP, Messous D, Thibault V, Imbert-Bismut F, Poynard T: Noninvasive prediction of fibrosis in patients with chronic hepatitis C. Hepatology 2003, 37:1220-1221, author reply 1221.

30. Guechot J, Loria A, Serfaty L, Giral P, Giboudeau J, Poupon R: Serum hyaluronan as a marker of liver fibrosis in chronic viral hepatitis C: effect of alpha-interferon therapy. J Hepatol 1995, 22:22-26.

31. Pares A, Deulofeu R, Gimenez A, Caballeria L, Bruguera M, Caballeria J, Ballesta AM, Rodes J: Serum hyaluronate reflects hepatic fibrogenesis in alcoholic liver disease and is useful as a marker of fibrosis. Hepatology 1996, 24:1399-1403.

32. McHutchison JG, Blatt LM, de Medina M, Craig JR, Conrad A, Schiff ER, Tong MJ: Measurement of serum hyaluronic acid in patients with chronic hepatitis $C$ and its relationship to liver histology. Consensus Interferon Study Group. J Gastroenterol Hepatol 2000, 15:945-951.

33. Hayasaka A, Saisho H: Serum markers as tools to monitor liver fibrosis. Digestion 1998, 59:381-384.

34. Guechot J, Laudat A, Loria A, Serfaty L, Poupon R, Giboudeau J: Diagnostic accuracy of hyaluronan and type III procollagen aminoterminal peptide serum assays as markers of liver fibrosis in chronic viral hepatitis C evaluated by ROC curve analysis. Clin Chem 1996, 42:558-563.

35. Fabris C, Falleti E, Federico E, Toniutto P, Pirisi M: A comparison of four serum markers of fibrosis in the diagnosis of cirrhosis. Ann Clin Biochem 1997, 34(Pt 2):151-155.

36. George DK, Ramm GA, Walker NI, Powell LW, Crawford DH: Elevated serum type IV collagen: a sensitive indicator of the presence of cirrhosis in haemochromatosis. J Hepatol 1999, 31:47-52.

37. Murawaki Y, Ikuta Y, Koda M, Yamada S, Kawasaki H: Comparison of serum $7 \mathrm{~S}$ fragment of type IV collagen and serum central triple-helix of type IV collagen for assessment of liver fibrosis in patients with chronic viral liver disease. J Hepatol 1996, 24:148-154.

38. Boeker KH, Haberkorn Cl, Michels D, Flemming P, Manns MP, Lichtinghagen R: Diagnostic potential of circulating TIMP-1 and MMP-2 as markers of liver fibrosis in patients with chronic hepatitis C. Clin Chim Acta 2002, 316:71-81.

39. Zhang BB, Cai WM, Weng HL, Hu ZR, Lu J, Zheng M, Liu RH: Diagnostic value of platelet derived growth factor- $B B$, transforming growth factorbeta1, matrix metalloproteinase-1, and tissue inhibitor of matrix metalloproteinase- 1 in serum and peripheral blood mononuclear cells for hepatic fibrosis. World J Gastroenterol 2003, 9:2490-2496.

40. Johansen JS, Christoffersen P, Moller S, Price PA, Henriksen JH, Garbarsch C, Bendtsen F: Serum YKL-40 is increased in patients with hepatic fibrosis. J Hepatol 2000, 32:911-920.

41. Kanzler S, Baumann M, Schirmacher P, Dries V, Bayer E, Gerken G, Dienes HP, Lohse AW: Prediction of progressive liver fibrosis in hepatitis
C infection by serum and tissue levels of transforming growth factorbeta. J Viral Hepat 2001, 8:430-437.

42. Patel K, Gordon SC, Jacobson I, Hezode C, Oh E, Smith KM, Pawlotsky JM, McHutchison JG: Evaluation of a panel of non-invasive serum markers to differentiate mild from moderate-to-advanced liver fibrosis in chronic hepatitis C patients. J Hepatol 2004, 41:935-942.

43. Zaman A, Rosen HR, Ingram K, Corless CL, Oh E, Smith K: Assessment of FIBROSpect II to detect hepatic fibrosis in chronic hepatitis $C$ patients. Am J Med 2007, 120:280, e289-214.

44. Rosenberg WM, Voelker M, Thiel R, Becka M, Burt A, Schuppan D, Hubscher S, Roskams T, Pinzani M, Arthur MJ: Serum markers detect the presence of liver fibrosis: a cohort study. Gastroenterology 2004, 127:1704-1713.

45. Leroy V, Monier F, Bottari S, Trocme C, Sturm N, Hilleret MN, Morel F, Zarski JP: Circulating matrix metalloproteinases 1, 2, 9 and their inhibitors TIMP-1 and TIMP-2 as serum markers of liver fibrosis in patients with chronic hepatitis C: comparison with PIIINP and hyaluronic acid. Am J Gastroenterol 2004, 99:271-279.

46. Murawaki Y, Ikuta Y, Nishimura Y, Koda M, Kawasaki H: Serum markers for connective tissue turnover in patients with chronic hepatitis $B$ and chronic hepatitis C: a comparative analysis. J Hepatol 1995, 23:145-152.

47. Murawaki Y, Ikuta Y, Okamoto K, Koda M, Kawasaki H: Diagnostic value of serum markers of connective tissue turnover for predicting histological staging and grading in patients with chronic hepatitis C. J Gastroenterol 2001, 36:399-406.

48. Suzuki A, Angulo P, Lymp J, Li D, Satomura S, Lindor K: Hyaluronic acid, an accurate serum marker for severe hepatic fibrosis in patients with nonalcoholic fatty liver disease. Liver Int 2005, 25:779-786.

49. Halfon P, Bourliere M, Penaranda G, Deydier R, Renou C, Botta-Fridlund D, Tran A, Portal I, Allemand I, Rosenthal-Allieri A, Ouzan D: Accuracy of hyaluronic acid level for predicting liver fibrosis stages in patients with hepatitis C virus. Comp Hepatol 2005, 4:6.

50. Hakala BE, White C, Recklies AD: Human cartilage gp-39, a major secretory product of articular chondrocytes and synovial cells, is a mammalian member of a chitinase protein family. J Biol Chem 1993, 268:25803-25810.

51. Saitou Y, Shiraki K, Yamanaka Y, Yamaguchi Y, Kawakita T, Yamamoto N, Sugimoto K, Murata K, Nakano T: Noninvasive estimation of liver fibrosis and response to interferon therapy by a serum fibrogenesis marker, YKL-40, in patients with HCV-associated liver disease. World J Gastroenterol 2005, 11:476-481.

52. Sanvisens A, Serra I, Tural C, Tor J, Ojanguren I, Barluenga E, Rey-Joly C, Clotet B, Muga R: Hyaluronic acid, transforming growth factor-beta1 and hepatic fibrosis in patients with chronic hepatitis $C$ virus and human immunodeficiency virus co-infection. J Viral Hepat 2009, 16:513-518.

53. Schiavon LL, Carvalho-Filho RJ, Narciso-Schiavon JL, Medina-Pestana JO, Lanzoni VP, Ferraz ML, Silva AE: YKL-40 and hyaluronic acid (HA) as noninvasive markers of liver fibrosis in kidney transplant patients with HCV chronic infection. Scand J Gastroenterol 2010, 45:615-622.

54. Felig P: The glucose-alanine cycle. Metabolism 1973, 22:179-207.

55. Daxboeck F, Gattringer R, Mustafa S, Bauer C, Assadian O: Elevated serum alanine aminotransferase (ALT) levels in patients with serologically verified Mycoplasma pneumoniae pneumonia. Clin Microbiol Infect 2005, 11:507-510.

56. Sherman KE: Alanine aminotransferase in clinical practice. A review. Arch Intern Med 1991, 151:260-265.

57. Dufour DR, Lott JA, Nolte FS, Gretch DR, Koff RS, Seeff LB: Diagnosis and monitoring of hepatic injury. I. Performance characteristics of laboratory tests. Clin Chem 2000, 46:2027-2049.

58. Akkaya O, Kiyici M, Yilmaz Y, Ulukaya E, Yerci O: Clinical significance of activity of ALT enzyme in patients with hepatitis C virus. World J Gastroenterol 2007, 13:5481-5485.

59. Kim HJ, Oh SW, Kim DJ, Choi EY: Abundance of immunologically active alanine aminotransferase in sera of liver cirrhosis and hepatocellular carcinoma patients. Clin Chem 2009, 55:1022-1025.

60. Shiffman ML, Diago M, Tran A, Pockros P, Reindollar R, Prati D, RodriguezTorres M, Lardelli P, Blotner S, Zeuzem S: Chronic hepatitis C in patients with persistently normal alanine transaminase levels. Clin Gastroenterol Hepatol 2006, 4:645-652.

61. Okuda M, Li K, Beard MR, Showalter LA, Scholle F, Lemon SM, Weinman SA: Mitochondrial injury, oxidative stress, and antioxidant gene expression 
are induced by hepatitis C virus core protein. Gastroenterology 2002 122:366-375

62. Zechini B, Pasquazzi C, Aceti A: Correlation of serum aminotransferases with HCV RNA levels and histological findings in patients with chronic hepatitis $C$ : the role of serum aspartate transaminase in the evaluation of disease progression. Eur J Gastroenterol Hepatol 2004, 16:891-896.

63. Cedrone A, Covino M, Caturelli E, Pompili M, Lorenzelli G, Villani MR, Valle D, Sperandeo M, Rapaccini GL, Gasbarrini G: Utility of alpha-fetoprotein (AFP) in the screening of patients with virus-related chronic liver disease: does different viral etiology influence AFP levels in HCC? A study in 350 western patients. Hepatogastroenterology 2000, 47:1654-1658.

64. Chu CW, Hwang SJ, Luo JC, Lai CR, Tsay SH, Li CP, Wu JC, Chang FY, Lee SD: Clinical, virologic, and pathologic significance of elevated serum alpha-fetoprotein levels in patients with chronic hepatitis C. J Clin Gastroenterol 2001, 32:240-244.

65. Chen TM, Huang PT, Tsai MH, Lin LF, Liu CC, Ho KS, Siauw CP, Chao PL, Tung JN: Predictors of alpha-fetoprotein elevation in patients with chronic hepatitis $C$, but not hepatocellular carcinoma, and its normalization after pegylated interferon alfa 2a-ribavirin combination therapy. J Gastroenterol Hepatol 2007, 22:669-675.

66. Tamura Y, Yamagiwa S, Aoki Y, Kurita S, Suda T, Ohkoshi S, Nomoto M, Aoyagi $Y$ : Serum alpha-fetoprotein levels during and after interferon therapy and the development of hepatocellular carcinoma in patients with chronic hepatitis C. Dig Dis Sci 2009, 54:2530-2537.

67. Aster RH: Pooling of platelets in the spleen: role in the pathogenesis of "hypersplenic" thrombocytopenia. J Clin Invest 1966, 45:645-657.

68. Kawasaki T, Takeshita A, Souda K, Kobayashi Y, Kikuyama M, Suzuki F, Kageyama F, Sasada Y, Shimizu E, Murohisa G, et al: Serum thrombopoietin levels in patients with chronic hepatitis and liver cirrhosis. Am J Gastroenterol 1999, 94:1918-1922.

69. Adinolfi LE, Giordano MG, Andreana A, Tripodi MF, Utili R, Cesaro G, Ragone E, Durante Mangoni E, Ruggiero G: Hepatic fibrosis plays a central role in the pathogenesis of thrombocytopenia in patients with chronic viral hepatitis. Br J Haematol 2001, 113:590-595.

70. Lackner C, Struber G, Liegl B, Leibl S, Ofner P, Bankuti C, Bauer B, Stauber RE: Comparison and validation of simple noninvasive tests for prediction of fibrosis in chronic hepatitis C. Hepatology 2005, 41:1376-1382

71. Croquet V, Vuillemin E, Ternisien C, Pilette C, Oberti F, Gallois Y, Trossaert M, Rousselet MC, Chappard D, Cales P: Prothrombin index is an indirect marker of severe liver fibrosis. Eur J Gastroenterol Hepatol 2002, 14:1133-1141.

72. Pilette C, Oberti F, Aube C, Rousselet MC, Bedossa P, Gallois Y, Rifflet $H$, Cales $P$ : Non-invasive diagnosis of esophageal varices in chronic liver diseases. J Hepatol 1999, 31:867-873.

73. Craxi A, Camma C, Giunta M: Clinical aspects of bleeding complications in cirrhotic patients. Blood Coagul Fibrinolysis 2000, 11(Suppl 1):S75-79.

74. Sheth SG, Flamm SL, Gordon FD, Chopra S: AST/ALT ratio predicts cirrhosis in patients with chronic hepatitis $C$ virus infection. $A m$ J Gastroenterol 1998, 93:44-48.

75. Reedy DW, Loo AT, Levine RA: AST/ALT ratio > or $=1$ is not diagnostic of cirrhosis in patients with chronic hepatitis C. Dig Dis Sci 1998, 43:2156-2159.

76. Giannini E, Risso D, Botta F, Chiarbonello B, Fasoli A, Malfatti F, Romagnoli P, Testa E, Ceppa P, Testa R: Validity and clinical utility of the aspartate aminotransferase-alanine aminotransferase ratio in assessing disease severity and prognosis in patients with hepatitis $C$ virus-related chronic liver disease. Arch Intern Med 2003, 163:218-224.

77. Fujii H, Enomoto M, Fukushima W, Ohfuji S, Mori M, Kobayashi S, Iwai S, Morikawa $\mathrm{H}$, Tamori A, Sakaguchi $\mathrm{H}$, et al: Noninvasive laboratory tests proposed for predicting cirrhosis in patients with chronic hepatitis $\mathrm{C}$ are also useful in patients with non-alcoholic steatohepatitis. J Gastroenterol 2009, 44:608-614.

78. Poynard T, Morra R, Halfon P, Castera L, Ratziu V, Imbert-Bismut F, Naveau S, Thabut D, Lebrec D, Zoulim F, et al: Meta-analyses of FibroTest diagnostic value in chronic liver disease. BMC Gastroenterol 2007, 7:40.

79. Cales P, Oberti F, Michalak S, Hubert-Fouchard I, Rousselet MC, Konate A, Gallois Y, Ternisien C, Chevailler A, Lunel F: A novel panel of blood markers to assess the degree of liver fibrosis. Hepatology 2005, 42:1373-1381.

80. Bourliere M, Penaranda G, Renou C, Botta-Fridlund D, Tran A, Portal I, Lecomte L, Castellani P, Rosenthal-Allieri MA, Gerolami R, et al: Validation and comparison of indexes for fibrosis and cirrhosis prediction in chronic hepatitis C patients: proposal for a pragmatic approach classification without liver biopsies. J Viral Hepat 2006, 13:659-670.

81. Parise ER, Oliveira AC, Figueiredo-Mendes C, Lanzoni V, Martins J, Nader H, Ferraz ML: Noninvasive serum markers in the diagnosis of structural liver damage in chronic hepatitis C virus infection. Liver Int 2006, 26:1095-1099.

82. de Ledinghen V, Douvin C, Kettaneh A, Ziol M, Roulot D, Marcellin P, Dhumeaux D, Beaugrand M: Diagnosis of hepatic fibrosis and cirrhosis by transient elastography in HIV/hepatitis C virus-coinfected patients. J Acquir Immune Defic Syndr 2006, 41:175-179.

83. Halfon $P$, Bacq $Y$, De Muret $A$, Penaranda G, Bourliere M, Ouzan D, Tran A, Botta D, Renou C, Brechot MC, et al: Comparison of test performance profile for blood tests of liver fibrosis in chronic hepatitis C. J Hepatol 2007, 46:395-402.

84. Leroy $\mathrm{V}$, Halfon P, Bacq Y, Boursier J, Rousselet MC, Bourliere M, de Muret A, Sturm N, Hunault G, Penaranda G, et al: Diagnostic accuracy, reproducibility and robustness of fibrosis blood tests in chronic hepatitis C: a meta-analysis with individual data. Clin Biochem 2008, 41:1368-1376.

85. Cales P, de Ledinghen V, Halfon P, Bacq Y, Leroy V, Boursier J, Foucher J, Bourliere M, de Muret A, Sturm N, et al: Evaluating the accuracy and increasing the reliable diagnosis rate of blood tests for liver fibrosis in chronic hepatitis C. Liver Int 2008, 28:1352-1362.

86. Kamphues C, Lotz K, Rocken C, Berg T, Eurich D, Pratschke J, Neuhaus P, Neumann UP: Chances and limitations of non-invasive tests in the assessment of liver fibrosis in liver transplant patients. Clin Transplant 2010, 24:652-659.

87. Teare JP, Sherman D, Greenfield SM, Simpson J, Bray G, Catterall AP, Murray-Lyon IM, Peters TJ, Williams R, Thompson RP: Comparison of serum procollagen III peptide concentrations and PGA index for assessment of hepatic fibrosis. Lancet 1993, 342:895-898.

88. Naveau S, Poynard T, Benattar C, Bedossa P, Chaput JC: Alpha-2macroglobulin and hepatic fibrosis. Diagnostic interest. Dig Dis Sci 1994, 39:2426-2432.

89. Oberti F, Valsesia E, Pilette C, Rousselet MC, Bedossa P, Aube C, Gallois Y, Rifflet H, Maiga MY, Penneau-Fontbonne D, Cales P: Noninvasive diagnosis of hepatic fibrosis or cirrhosis. Gastroenterology 1997, 113:1609-1616.

90. Poynard T, McHutchison J, Manns M, Myers RP, Albrecht J: Biochemical surrogate markers of liver fibrosis and activity in a randomized trial of peginterferon alfa-2b and ribavirin. Hepatology 2003, 38:481-492.

91. Poynard T, Munteanu M, Imbert-Bismut F, Charlotte F, Thabut D, Le Calvez S, Messous D, Thibault V, Benhamou Y, Moussalli J, Ratziu V: Prospective analysis of discordant results between biochemical markers and biopsy in patients with chronic hepatitis C. Clin Chem 2004, 50:1344-1355.

92. Naveau S, Raynard B, Ratziu V, Abella A, Imbert-Bismut F, Messous D, Beuzen F, Capron F, Thabut D, Munteanu M, et al: Biomarkers for the prediction of liver fibrosis in patients with chronic alcoholic liver disease. Clin Gastroenterol Hepatol 2005, 3:167-174.

93. Sebastiani $G$, Alberti A: Non invasive fibrosis biomarkers reduce but not substitute the need for liver biopsy. World I Gastroenterol 2006, 12:3682-3694.

94. Friedrich-Rust M, Rosenberg W, Parkes J, Herrmann E, Zeuzem S, Sarrazin C: Comparison of ELF, FibroTest and FibroScan for the non-invasive assessment of liver fibrosis. BMC Gastroenterol 2010, 10:103.

95. Halfon $P$, Imbert-Bismut $F$, Messous $D$, Antoniotti $G$, Benchetrit $D$, CartLamy P, Delaporte G, Doutheau D, Klump T, Sala M, et al: A prospective assessment of the inter-laboratory variability of biochemical markers of fibrosis (FibroTest) and activity (ActiTest) in patients with chronic liver disease. Comp Hepatol 2002, 1:3.

96. Poynard T, Imbert-Bismut F, Ratziu V, Chevret S, Jardel C, Moussalli J, Messous D, Degos F: Biochemical markers of liver fibrosis in patients infected by hepatitis $C$ virus: longitudinal validation in a randomized trial. J Viral Hepat 2002, 9:128-133.

97. Rossi E, Adams L, Prins A, Bulsara M, de Boer B, Garas G, MacQuillan G, Speers $D$, Jeffrey $G$ : Validation of the FibroTest biochemical markers score in assessing liver fibrosis in hepatitis C patients. Clin Chem 2003, 49:450-454.

98. Ngo Y, Munteanu M, Messous D, Charlotte F, Imbert-Bismut F, Thabut D, Lebray P, Thibault V, Benhamou Y, Moussalli J, et al: A prospective analysis of the prognostic value of biomarkers (FibroTest) in patients with chronic hepatitis C. Clin Chem 2006, 52:1887-1896. 
99. Halfon P, Bourliere M, Deydier R, Botta-Fridlund D, Renou C, Tran A, Portal I, Allemand I, Bertrand JJ, Rosenthal-Allieri A, et al: Independent prospective multicenter validation of biochemical markers (fibrotest-actitest) for the prediction of liver fibrosis and activity in patients with chronic hepatitis C: the fibropaca study. Am J Gastroenterol 2006, 101:547-555.

100. Halfon P, Munteanu M, Poynard T: FibroTest-ActiTest as a non-invasive marker of liver fibrosis. Gastroenterol Clin Biol 2008, 32:22-39.

101. Myers RP, De Torres M, Imbert-Bismut F, Ratziu V, Charlotte F, Poynard T: Biochemical markers of fibrosis in patients with chronic hepatitis C: a comparison with prothrombin time, platelet count, and age-platelet index. Dig Dis Sci 2003, 48:146-153.

102. Bedossa $P$, Dargere D, Paradis V: Sampling variability of liver fibrosis in chronic hepatitis C. Hepatology 2003, 38:1449-1457.

103. Colletta C, Smirne C, Fabris C, Toniutto P, Rapetti R, Minisini R, Pirisi M: Value of two noninvasive methods to detect progression of fibrosis among HCV carriers with normal aminotransferases. Hepatology 2005, 42:838-845.

104. Shaheen AA, Myers RP: Systematic review and meta-analysis of the diagnostic accuracy of fibrosis marker panels in patients with HIV/ hepatitis C coinfection. HIV Clin Trials 2008, 9:43-51.

105. Cales P, Boursier J, Bertrais S, Oberti F, Gallois Y, Fouchard-Hubert I, Dib N, Zarski JP, Rousselet MC: Optimization and robustness of blood tests for liver fibrosis and cirrhosis. Clin Biochem 2010, 43:1315-1322.

106. Koda M, Matunaga Y, Kawakami M, Kishimoto Y, Suou T, Murawaki Y: Fibrolndex, a practical index for predicting significant fibrosis in patients with chronic hepatitis C. Hepatology 2007, 45:297-306.

107. Lee MH, Cheong JY, Um SH, Seo YS, Kim DJ, Hwang SG, Yang JM, Han KH, Cho SW: Comparison of surrogate serum markers and transient elastography (Fibroscan) for assessing cirrhosis in patients with chronic viral hepatitis. Dig Dis Sci 2010, 55:3552-3560.

108. El-Shabrawi MH, Mohsen NA, Sherif MM, El-Karaksy HM, Abou-Yosef H, ElSayed HM, Riad H, Bahaa N, Isa M, El-Hennawy A: Noninvasive assessment of hepatic fibrosis and necroinflammatory activity in Egyptian children with chronic hepatitis $C$ virus infection using FibroTest and ActiTest. Eur J Gastroenterol Hepatol 2010, 22:946-951.

109. Poynard T, Ratziu V, Naveau S, Thabut D, Charlotte F, Messous D, Capron D, Abella A, Massard J, Ngo Y, et al: The diagnostic value of biomarkers (SteatoTest) for the prediction of liver steatosis. Comp Hepatol 2005, 4:10.

110. Lok AS, Ghany MG, Goodman ZD, Wright EC, Everson GT, Sterling RK, Everhart JE, Lindsay KL, Bonkovsky HL, Di Bisceglie AM, et al: Predicting cirrhosis in patients with hepatitis $C$ based on standard laboratory tests: results of the HALT-C cohort. Hepatology 2005, 42:282-292.

111. Cheong JY, Um SH, Seo YS, Kim DJ, Hwang SG, Lee YJ, Cho M, Yang JM, Kim YB, Park YN, Cho SW: Non-Invasive Index for Predicting Significant Liver Fibrosis: Comparison of Diagnostic Performances in Patients with Chronic Hepatitis B and C. Dig Dis Sci 2010, 56:555-563.

112. Islam S, Antonsson L, Westin J, Lagging M: Cirrhosis in hepatitis $C$ virusinfected patients can be excluded using an index of standard biochemical serum markers. Scand J Gastroenterol 2005, 40:867-872.

113. Ohta T, Sakaguchi K, Fujiwara A, Fujioka S, Iwasaki Y, Makino Y, Araki Y, Shiratori $Y$ : Simple surrogate index of the fibrosis stage in chronic hepatitis $C$ patients using platelet count and serum albumin level. Acta Med Okayama 2006, 60:77-84

114. Pohl A, Behling C, Oliver D, Kilani M, Monson P, Hassanein T: Serum aminotransferase levels and platelet counts as predictors of degree of fibrosis in chronic hepatitis C virus infection. Am J Gastroenterol 2001, 96:3142-3146.

115. Cheung RC, Currie S, Shen H, Bini EJ, Ho SB, Anand BS, Hu KQ, Wright TL, Morgan TR: Can we predict the degree of fibrosis in chronic hepatitis $C$ patients using routine blood tests in our daily practice? J Clin Gastroenterol 2008, 42:827-834.

116. Bonacini M, Hadi G, Govindarajan S, Lindsay KL: Utility of a discriminant score for diagnosing advanced fibrosis or cirrhosis in patients with chronic hepatitis C virus infection. Am J Gastroenterol 1997, 92:1302-1304.

117. Adams LA, Bulsara M, Rossi E, DeBoer B, Speers D, George J, Kench J, Farrell G, McCaughan GW, Jeffrey GP: Hepascore: an accurate validated predictor of liver fibrosis in chronic hepatitis C infection. Clin Chem 2005, 51:1867-1873.

118. Leroy V, Hilleret MN, Sturm N, Trocme C, Renversez JC, Faure P, Morel F, Zarski JP: Prospective comparison of six non-invasive scores for the diagnosis of liver fibrosis in chronic hepatitis C. J Hepatol 2007, 46:775-782.

119. Becker L, Salameh W, Sferruzza A, Zhang K, ng Chen R, Malik R, Reitz R, Nasser I, Afdhal NH: Validation of hepascore, compared with simple indices of fibrosis, in patients with chronic hepatitis $C$ virus infection in United States. Clin Gastroenterol Hepatol 2009, 7:696-701.

120. Guechot J, Lasnier E, Sturm N, Paris A, Zarski JP: Automation of the Hepascore and validation as a biochemical index of liver fibrosis in patients with chronic hepatitis C from the ANRS HC EP 23 Fibrostar cohort. Clin Chim Acta 2010, 411:86-91.

121. Kelleher TB, Mehta SH, Bhaskar R, Sulkowski M, Astemborski J, Thomas DL, Moore RE, Afdhal NH: Prediction of hepatic fibrosis in HIV/HCV coinfected patients using serum fibrosis markers: the SHASTA index. J Hepatol 2005, 43:78-84.

122. Sterling RK, Lissen E, Clumeck N, Sola R, Correa MC, Montaner J, M SS, Torriani FJ, Dieterich DT, Thomas DL, et al: Development of a simple noninvasive index to predict significant fibrosis in patients with HIV/HCV coinfection. Hepatology 2006, 43:1317-1325.

123. Vallet-Pichard A, Mallet V, Nalpas B, Verkarre V, Nalpas A, Dhalluin-Venier V, Fontaine $\mathrm{H}, \mathrm{Pol}$ S: FIB-4: an inexpensive and accurate marker of fibrosis in HCV infection. comparison with liver biopsy and fibrotest. Hepatology 2007, 46:32-36

124. Mallet V, Dhalluin-Venier V, Roussin C, Bourliere M, Pettinelli ME, Giry C, Vallet-Pichard A, Fontaine H, Pol S: The accuracy of the FIB-4 index for the diagnosis of mild fibrosis in chronic hepatitis B. Aliment Pharmacol Ther 2009, 29:409-415.

125. Sud A, Hui JM, Farrell GC, Bandara P, Kench JG, Fung C, Lin R, Samarasinghe D, Liddle C, McCaughan GW, George J: Improved prediction of fibrosis in chronic hepatitis $C$ using measures of insulin resistance in a probability index. Hepatology 2004, 39:1239-1247.

126. Testa R, Testa E, Giannini E, Borro P, Milazzo S, Isola L, Ceppa P, Lantieri PB, Risso D: Noninvasive ratio indexes to evaluate fibrosis staging in chronic hepatitis C: role of platelet count/spleen diameter ratio index. J Intern Med 2006, 260:142-150.

127. Fortunato G, Castaldo G, Oriani G, Cerini R, Intrieri M, Molinaro E, Gentile I, Borgia G, Piazza M, Salvatore F, Sacchetti L: Multivariate discriminant function based on six biochemical markers in blood can predict the cirrhotic evolution of chronic hepatitis. Clin Chem 2001, 47:1696-1700.

128. Aube C, Oberti F, Korali N, Namour MA, Loisel D, Tanguy JY, Valsesia E, Pilette C, Rousselet MC, Bedossa P, et al: Ultrasonographic diagnosis of hepatic fibrosis or cirrhosis. J Hepatol 1999, 30:472-478.

129. Mathiesen UL, Franzen LE, Aselius H, Resjo M, Jacobsson L, Foberg U, Fryden A, Bodemar G: Increased liver echogenicity at ultrasound examination reflects degree of steatosis but not of fibrosis in asymptomatic patients with mild/moderate abnormalities of liver transaminases. Dig Liver Dis 2002, 34:516-522.

130. Colli A, Fraquelli M, Andreoletti M, Marino B, Zuccoli E, Conte D: Severe liver fibrosis or cirrhosis: accuracy of US for detection-analysis of 300 cases. Radiology 2003, 227:89-94.

131. Zheng RQ, Wang QH, Lu MD, Xie SB, Ren J, Su ZZ, Cai YK, Yao JL: Liver fibrosis in chronic viral hepatitis: an ultrasonographic study. World J Gastroenterol 2003, 9:2484-2489.

132. Colli A, Colucci A, Paggi S, Fraquelli M, Massironi S, Andreoletti M, Michela V, Conte D: Accuracy of a predictive model for severe hepatic fibrosis or cirrhosis in chronic hepatitis C. World J Gastroenterol 2005, 11:7318-7322.

133. Shen L, Li JQ, Zeng MD, Lu LG, Fan ST, Bao H: Correlation between ultrasonographic and pathologic diagnosis of liver fibrosis due to chronic virus hepatitis. World J Gastroenterol 2006, 12:1292-1295.

134. Sandrin L, Tanter M, Gennisson JL, Catheline S, Fink M: Shear elasticity probe for soft tissues with 1-D transient elastography. IEEE Trans Ultrason Ferroelectr Frea Control 2002, 49:436-446.

135. Sandrin L, Fourquet B, Hasquenoph JM, Yon S, Fournier C, Mal F, Christidis C, Ziol M, Poulet B, Kazemi F, et al: Transient elastography: a new noninvasive method for assessment of hepatic fibrosis. Ultrasound Med Biol 2003, 29:1705-1713.

136. Colloredo G, Guido M, Sonzogni A, Leandro G: Impact of liver biopsy size on histological evaluation of chronic viral hepatitis: the smaller the sample, the milder the disease. J Hepatol 2003, 39:239-244.

137. Cobbold JF, Morin S, Taylor-Robinson SD: Transient elastography for the assessment of chronic liver disease: ready for the clinic? World J Gastroenterol 2007, 13:4791-4797. 
138. Kettaneh A, Marcellin P, Douvin C, Poupon R, Ziol M, Beaugrand M, de Ledinghen $V$ : Features associated with success rate and performance of FibroScan measurements for the diagnosis of cirrhosis in HCV patients: a prospective study of 935 patients. J Hepatol 2007, 46:628-634.

139. Foucher J, Chanteloup E, Vergniol J, Castera L, Le Bail B, Adhoute X, Bertet J, Couzigou P, de Ledinghen V: Diagnosis of cirrhosis by transient elastography (FibroScan): a prospective study. Gut 2006, 55:403-408.

140. Maor Y, Halfon P, Bashari D, Penaranda G, Morali G, Klar R, Bar-Meir S, Martinowitz U, Oren R: Fibrotest or Fibroscan for evaluation of liver fibrosis in haemophilia patients infected with hepatitis C. Haemophilia 2010, 16:148-154.

141. Friedrich-Rust M, Ong MF, Herrmann E, Dries V, Samaras P, Zeuzem S, Sarrazin C: Real-time elastography for noninvasive assessment of liver fibrosis in chronic viral hepatitis. AJR Am J Roentgenol 2007, 188:758-764.

142. Fraquelli M, Rigamonti C, Casazza G, Conte D, Donato MF, Ronchi G, Colombo M: Reproducibility of transient elastography in the evaluation of liver fibrosis in patients with chronic liver disease. Gut 2007, 56:968-973.

143. Vizzutti F, Arena U, Romanelli RG, Rega L, Foschi M, Colagrande S Petrarca A, Moscarella S, Belli G, Zignego AL, et al: Liver stiffness measurement predicts severe portal hypertension in patients with HCVrelated cirrhosis. Hepatology 2007, 45:1290-1297.

144. de Ledinghen $V$, Vergniol J: Transient elastography for the diagnosis of liver fibrosis. Expert Rev Med Devices 2010, 7:811-823.

145. Corpechot C, El Naggar A, Poujol-Robert A, Ziol M, Wendum D, Chazouilleres $O$, de Ledinghen V, Dhumeaux D, Marcellin P, Beaugrand M, Poupon R: Assessment of biliary fibrosis by transient elastography in patients with PBC and PSC. Hepatology 2006, 43:1118-1124.

146. Ganne-Carrie N, Ziol M, de Ledinghen V, Douvin C, Marcellin P, Castera L, Dhumeaux D, Trinchet JC, Beaugrand M: Accuracy of liver stiffness measurement for the diagnosis of cirrhosis in patients with chronic liver diseases. Hepatology 2006, 44:1511-1517.

147. Shaheen AA, Wan AF, Myers RP: FibroTest and FibroScan for the prediction of hepatitis C-related fibrosis: a systematic review of diagnostic test accuracy. Am J Gastroenterol 2007, 102:2589-2600.

148. Friedrich-Rust M, Wunder K, Kriener S, Sotoudeh F, Richter S, Bojunga J, Herrmann E, Poynard T, Dietrich CF, Vermehren J, et al: Liver fibrosis in viral hepatitis: noninvasive assessment with acoustic radiation force impulse imaging versus transient elastography. Radiology 2009, 252:595-604

149. Sanchez-Conde M, Montes-Ramirez ML, Miralles P, Alvarez JM, Bellon JM, Ramirez M, Arribas JR, Gutierrez I, Lopez JC, Cosin J, et al: Comparison of transient elastography and liver biopsy for the assessment of liver fibrosis in HIV/hepatitis C virus-coinfected patients and correlation with noninvasive serum markers. J Viral Hepat 2010, 17:280-286.

150. Abu-Yousef MM: Duplex Doppler sonography of the hepatic vein in tricuspid regurgitation. AJR Am J Roentgenol 1991, 156:79-83.

151. Albrecht T, Blomley MJ, Cosgrove DO, Taylor-Robinson SD, Jayaram V, Eckersley R, Urbank A, Butler-Barnes J, Patel N: Non-invasive diagnosis of hepatic cirrhosis by transit-time analysis of an ultrasound contrast agent. Lancet 1999, 353:1579-1583.

152. Hirata M, Akbar SM, Horiike N, Onji M: Noninvasive diagnosis of the degree of hepatic fibrosis using ultrasonography in patients with chronic liver disease due to hepatitis C virus. Eur J Clin Invest 2001, 31:528-535.

153. Bonekamp S, Kamel I, Solga S, Clark J: Can imaging modalities diagnose and stage hepatic fibrosis and cirrhosis accurately? J Hepatol 2009, 50:17-35.

154. Lucidarme O, Baleston F, Cadi M, Bellin MF, Charlotte F, Ratziu V, Grenier PA: Non-invasive detection of liver fibrosis: Is superparamagnetic iron oxide particle-enhanced MR imaging a contributive technique? Eur Radiol 2003, 13:467-474.

155. Numminen K, Tervahartiala P, Halavaara J, Isoniemi H, Hockerstedt K: Noninvasive diagnosis of liver cirrhosis: magnetic resonance imaging presents special features. Scand J Gastroenterol 2005, 40:76-82.

156. Aguirre DA, Behling CA, Alpert E, Hassanein TI, Sirlin CB: Liver fibrosis: noninvasive diagnosis with double contrast material-enhanced MR imaging. Radiology 2006, 239:425-437.

157. Taura T, Nakamura K, Takashima S, Kaminou T, Yamada R, Shuto T, Wakasa K: Heterogeneity of hepatic parenchymal enhancement on computed tomography during arterial portography: quantitative analysis of correlation with severity of hepatic fibrosis. Hepatol Res 2001, 20:182-192.

158. Materne R, Annet L, Dechambre S, Sempoux C, Smith AM, Corot C, Horsmans $Y$, Van Beers BE: Dynamic computed tomography with lowand high-molecular-mass contrast agents to assess microvascular permeability modifications in a model of liver fibrosis. Clin Sci (Lond) 2002, 103:213-216

159. Wang S, Fu D, Xu M, Hu D: Advanced fuzzy cellular neural network: application to CT liver images. Artif Intell Med 2007, 39:65-77.

160. Castera L, Vergniol J, Foucher J, Le Bail B, Chanteloup E, Haaser M, Darriet M, Couzigou P, De Ledinghen V: Prospective comparison of transient elastography, Fibrotest, APRI, and liver biopsy for the assessment of fibrosis in chronic hepatitis C. Gastroenterology 2005, 128:343-350

161. Asselah T, Bieche I, Laurendeau I, Paradis V, Vidaud D, Degott C, Martinot M, Bedossa P, Valla D, Vidaud M, Marcellin P: Liver gene expression signature of mild fibrosis in patients with chronic hepatitis C. Gastroenterology 2005, 129:2064-2075.

162. Smith MW, Walters KA, Korth MJ, Fitzgibbon M, Proll S, Thompson JC, Yeh MM, Shuhart MC, Furlong JC, Cox PP, et al: Gene expression patterns that correlate with hepatitis $C$ and early progression to fibrosis in liver transplant recipients. Gastroenterology 2006, 130:179-187.

163. Huang H, Shiffman ML, Cheung RC, Layden TJ, Friedman S, Abar OT, Yee L, Chokkalingam AP, Schrodi SJ, Chan J, et al: Identification of two gene variants associated with risk of advanced fibrosis in patients with chronic hepatitis C. Gastroenterology 2006, 130:1679-1687.

164. Machida K, Cheng KT, Sung VM, Levine AM, Foung S, Lai MM: Hepatitis C virus induces toll-like receptor 4 expression, leading to enhanced production of beta interferon and interleukin-6. J Virol 2006, 80:866-874.

165. Huang H, Shiffman ML, Friedman S, Venkatesh R, Bzowej N, Abar OT, Rowland CM, Catanese JJ, Leong DU, Sninsky JJ, et al: A 7 gene signature identifies the risk of developing cirrhosis in patients with chronic hepatitis C. Hepatology 2007, 46:297-306.

166. Zeremski M, Petrovic LM, Chiriboga L, Brown QB, Yee HT, Kinkhabwala M, Jacobson IM, Dimova R, Markatou M, Talal AH: Intrahepatic levels of CXCR3-associated chemokines correlate with liver inflammation and fibrosis in chronic hepatitis C. Hepatology 2008, 48:1440-1450.

167. Zeremski M, Dimova R, Brown Q, Jacobson IM, Markatou M, Talal AH: Peripheral CXCR3-associated chemokines as biomarkers of fibrosis in chronic hepatitis C virus infection. J Infect Dis 2009, 200:1774-1780.

168. Kovalenko E, Tacke F, Gressner OA, Zimmermann HW, Lahme B, Janetzko A, Wiederholt T, Berg T, Muller T, Trautwein C, et al: Validation of connective tissue growth factor (CTGF/CCN2) and its gene polymorphisms as noninvasive biomarkers for the assessment of liver fibrosis. J Viral Hepat 2009, 16:612-620.

169. Sharma A, Chakraborti A, Das A, Dhiman RK, Chawla Y: Elevation of interleukin-18 in chronic hepatitis C: implications for hepatitis $C$ virus pathogenesis. Immunology 2009, 128:e514-522.

170. Caillot F, Hiron M, Goria O, Gueudin M, Francois A, Scotte M, Daveau M, Salier JP: Novel serum markers of fibrosis progression for the follow-up of hepatitis C virus-infected patients. Am J Pathol 2009, 175:46-53.

171. Gutierrez-Reyes G, Gutierrez-Ruiz MC, Kershenobich D: Liver fibrosis and chronic viral hepatitis. Arch Med Res 2007, 38:644-651.

172. Desmond PV, Patwardhan RV, Johnson RF, Schenker S: Impaired elimination of caffeine in cirrhosis. Dig Dis Sci 1980, 25:193-197.

173. Park GJ, Katelaris PH, Jones DB, Seow F, Le Couteur DG, Ngu MC: Validity of the $13 \mathrm{C}$-caffeine breath test as a noninvasive, quantitative test of liver function. Hepatology 2003, 38:1227-1236.

174. Manns MP, McHutchison JG, Gordon SC, Rustgi VK, Shiffman M, Reindollar R, Goodman ZD, Koury K, Ling M, Albrecht JK: Peginterferon alfa- $2 b$ plus ribavirin compared with interferon alfa- $2 b$ plus ribavirin for initial treatment of chronic hepatitis C: a randomised trial. Lancet 2001, 358:958-965.

175. Kumar D, Farrell GC, Fung C, George J: Hepatitis C virus genotype 3 is cytopathic to hepatocytes: Reversal of hepatic steatosis after sustained therapeutic response. Hepatology 2002, 36:1266-1272.

176. Abe S, Tabaru A, Ono M, Tai M, Narita R, Moriyama A, Otsuki M: High-dose interferon-alpha therapy lowers the levels of serum fibrogenesis markers over 5 years in chronic hepatitis C. Hepatol Res 2003, 25:22-31.

177. Derbala MF, Al Kaabi SR, El Dweik NZ, Pasic F, Butt MT, Yakoob R, AlMarri A, Amer AM, Morad N, Bener A: Treatment of hepatitis $C$ virus 
genotype 4 with peginterferon alfa-2a: impact of bilharziasis and fibrosis stage. World J Gastroenterol 2006, 12:5692-5698.

178. Takemoto R, Nakamuta M, Aoyagi Y, Fujino T, Yasutake K, Koga K,

Yoshimoto T, Miyahara T, Fukuizumi K, Wada Y, et al: Validity of FibroScan values for predicting hepatic fibrosis stage in patients with chronic HCV infection. J Dig Dis 2009, 10:145-148.

179. Vergniol J, Foucher J, Castera L, Bernard PH, Tournan R, Terrebonne E, Chanteloup E, Merrouche W, Couzigou P, de Ledinghen V: Changes of non-invasive markers and FibroScan values during HCV treatment. J Viral Hepat 2009, 16:132-140.

180. Halfon P, Carrat F, Bedossa P, Lambert J, Penaranda G, Perronne C, Pol S, Cacoub P: Effect of antiviral treatment on serum markers of liver fibrosis in HIV-hepatitis C virus-coinfected patients: the Fibrovic 2 Study - ANRS HC02. Antivir Ther 2009, 14:211-219.

181. Patel K, Benhamou Y, Yoshida EM, Kaita KD, Zeuzem S, Torbenson M, Pulkstenis E, Subramanian GM, McHutchison JG: An independent and prospective comparison of two commercial fibrosis marker panels (HCV FibroSURE and FIBROSpect II) during albinterferon alfa-2b combination therapy for chronic hepatitis C. J Viral Hepat 2009, 16:178-186.

doi:10.1186/1743-422X-8-53

Cite this article as: Ahmad et al: A brief review on molecular, genetic and imaging techniques for HCV fibrosis evaluation. Virology Journal $20118: 53$.

\section{Submit your next manuscript to BioMed Central} and take full advantage of:

- Convenient online submission

- Thorough peer review

- No space constraints or color figure charges

- Immediate publication on acceptance

- Inclusion in PubMed, CAS, Scopus and Google Scholar

- Research which is freely available for redistribution

Submit your manuscript at www.biomedcentral.com/submit 